Research Article

\title{
Autochthonous Acid-Producing Bacteria from Catfish (Clarias sp.) with Antibacterial Activity against Selected Fish Pathogens: A Preliminary Study
}

\author{
Asep Awaludin Prihanto $\mathbb{D}^{1,2,3}$ Happy Nursyam, ${ }^{1,2}$ Yoga Dwi Jatmiko, \\ and Royani L. Hayati ${ }^{3}$ \\ ${ }^{1}$ Dept. Fishery Product Technology, Faculty of Fisheries and Marine Sciences, Brawijaya University. Jl. Veteran, Malang, \\ East Java, Indonesia \\ ${ }^{2}$ Bio-Seafood Research Unit, Faculty of Fisheries and Marine Sciences, Brawijaya University. Jl. Veteran, Malang, \\ East Java, Indonesia \\ ${ }^{3}$ Coastal and Marine Science Center, Brawijaya University. Jl. Veteran, 65145 East Java, Indonesia \\ ${ }^{4}$ Dept. Biology, Faculty of Mathematics and Natural Sciences, Brawijaya University. Jl. Veteran, Malang, East Java, Indonesia \\ Correspondence should be addressed to Asep Awaludin Prihanto; asep_awa@ub.ac.id
}

Received 24 March 2019; Revised 8 November 2019; Accepted 23 January 2020; Published 1 March 2020

Academic Editor: Giuseppe Comi

Copyright (c) 2020 Asep Awaludin Prihanto et al. This is an open access article distributed under the Creative Commons Attribution License, which permits unrestricted use, distribution, and reproduction in any medium, provided the original work is properly cited.

\begin{abstract}
In this study, the application of an autochthonous microorganism as probiotic on catfish (Clarias sp.) was scarcely reported. This study aimed to obtain probiotic candidates from the digestive tract (intestinal and gastric) of catfish. A total of nine isolates were successfully isolated from the catfish. Almost all bacterial colonies were morphologically round, had flat edges, were yellow, and produced clear zones as a sign of producing acid during culture. The analysis showed that the three isolates had the best activity in inhibiting fish pathogen isolates. Furthermore, molecular analysis revealed that those three isolates were Bacillus velezensis UB-C1, Bacillus amyloliquifaciens UB-C5, and Bacillus cereus UB-C8. Interestingly, those three bacteria were non-lactic acid bacteria.
\end{abstract}

\section{Introduction}

Catfish production in Indonesia is in a very declining state due to various constraints in cultivation, including the number of diseases and decrease in the quality of aquatic aquaculture environment and feed provided. According to Rachman et al. [1], the application of intensive cultivation systems resulted in the declining environment carrying capacity. The impact of this activity causes disruption to the balance of microorganism populations on the aquatic environment. This usually is one of the reasons for increase of pathogenic organisms including parasites, bacteria, and viruses which causes fish diseases. Various pathogenic bacteria such as Vibrio sp., Aeromonas sp., and Pseudomonas sp., will cause disease in cultivated fish; hence, it needs to be anticipated.
Several types of bacteria found in the digestive tract of animals have an important role in improving feed utilization, fish health, and environmental quality [2]. In addition, several bacteria in the digestive tract produce several types of enzymes which may play a vital role in host metabolism. The intestine and stomach are the main places for food and organs to be colonized by microbes that play a role or contribute to the process of food digestion and immune function. Therefore, by isolating the normal bacterial flora from these organs, it may support the finding of potential probiotic candidates. One alternative approach that has been successfully carried out for improving aquaculture productivity is introducing live bacteria that have already been known to have beneficial effects on the growth of aquatic animals, known as probiotics. 
The origin bacteria which were found in the digestive tract have a mutual relationship with their host and use the host as their habitat. Many intestinal bacteria can synthesize vitamins, secrete enzymes, and help in digestion of nutrients, and the presence of native bacteria tends to suppress the growth of pathogenic bacteria, so they can protect the host and stimulate immune function [3-7]. This study aimed to determine the bacteria from the catfish (Clarias sp.) gastrointestinal tract that can be used for probiotics candidates against several pathogenic bacteria.

\section{Materials and Methods}

2.1. Fish Samples. Catfish (Clarias sp.) were purchased from a local fish farmer in Malang city, East Java, Indonesia. Fish samples were randomly collected from two ponds. Prior to the sampling, the ponds experienced an outbreak of diseases. Two survived catfishes were used as samples. Samples were immediately transported to a laboratory. Fish were aseptically dissected to take their intestine and stomach.

2.2. Isolation of Acid-Producing Bacteria. Isolation of digestive organs was carried out aseptically using surgical instruments. The stomach and intestines were removed from the fish. One gram samples were mildly crushed using mortal and put on $9 \mathrm{~mL}$ of saline solution. The diluted samples were plated onto de Man Rogosa-Sharpe (MRS) agar supplemented with $0.5 \%$ of $\mathrm{CaCO}_{3}$ [8]. Plates were incubated anaerobically in an anaerobic jar with an AnaeroGen ${ }^{\mathrm{TM}}$ system for $48-96$ hours at $37^{\circ} \mathrm{C}$.

2.3. Identification of Bacteria. All isolates with a clear zone were transferred to the fresh MRS agar medium. Colonies showing different morphology such as color, form, and elevation were purely subcultured. Only isolates with the antagonism activity toward fish pathogenic bacteria were further identified by using the molecular method. Bacterial DNA was extracted using the method described by Murray (by following the company manual procedure). 16s rDNA were amplified by using universal primers 27f ( $5^{\prime}$ - AGA GTT TGA TCC TGG CTC AG- $\left.3^{\prime}\right)$ and 1492r ( $5^{\prime}$ - GGT TAC CTT CTT ACG ACT $\left.\mathrm{T}-3^{\prime}\right)$ under PCR condition as follows: 35 cycles of $94^{\circ} \mathrm{C}$ for 5 mins, $94^{\circ} \mathrm{C}$ for $30 \mathrm{~s}, 55^{\circ} \mathrm{C}$ for $1 \mathrm{~min}$, and $72^{\circ} \mathrm{C}$ for $90 \mathrm{~s}$. Amplified nucleotides were purified using the QIA quick PCR purification kit (QIAGEN, GmbH, Germany). Prior to sequencing with Big Dye terminator sequencing on ABI PRISM 3100 DNA sequencer (Applied Biosystems), the amplified 16s rDNA were added with the sequenching primers, F1 ( $5^{\prime}$ GAGTTTGATCCTGGCT CAG-3'); F3 (5'-GTCCCGCAACGAGCGCAAC- $\left.3^{\prime}\right)$; R1 ( $5^{\prime}$-GTATTACCGCGGCTGCTGCTG G-3 $\left.3^{\prime}\right)$; R2 (5'-CATCGTTTACGGCGTGGAC-3'); R3 (5'TTGCGCTCGTCGTTGCG GACT- $\left.3^{\prime}\right)$; and R4 (5'ACGGGCGGTGTGATACAAG-3' ${ }^{\prime}$. Sequenced nucleotides were assembled using bioedit and aligned using ClustalX. The isolates identity was further checked using BLAST using the data on GenBank. The phylogenetic tree was performed followed the method of Dereeper et al. [9].
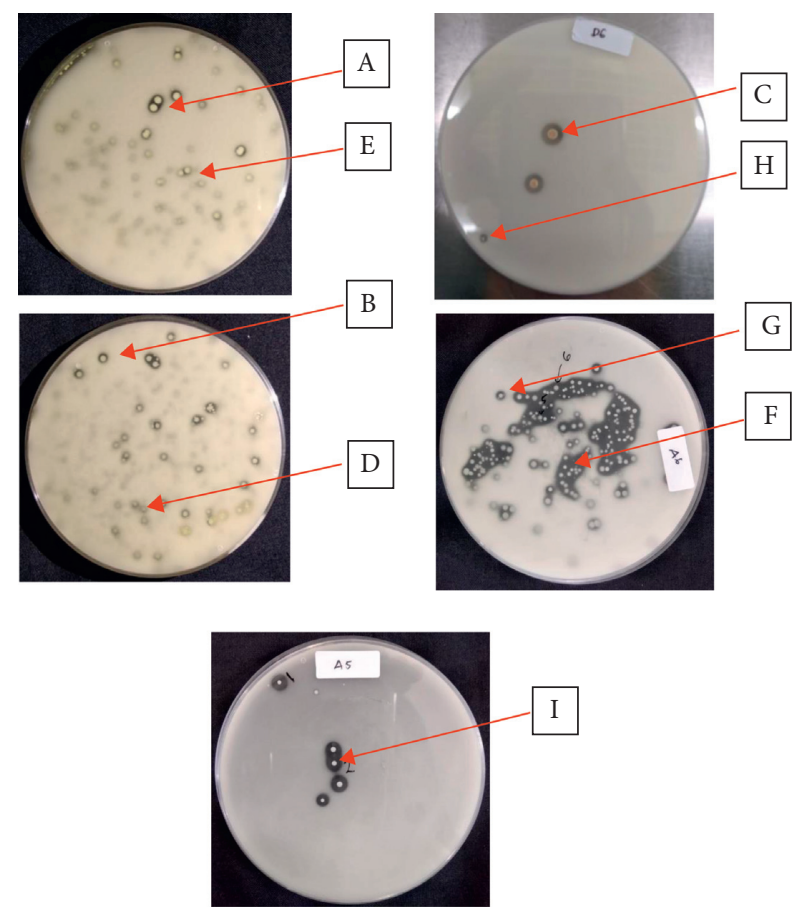

FIGURE 1: Selected colony morphology of catfish-autochthonous bacteria.

2.4. Antibacterial Assay. All isolates were screened for their antibacterial activity against clinical pathogen isolates. Vibrio harveyi, V. alginolyticus, Edwardsiella tarda, Pseudomonas aeruginosa, and Aeromonas hydrophila were obtained from Fish Disease Laboratory, Faculty of Fisheries and Marine Science, Brawijaya University. After 24 hours of incubation on the Luria Bertani broth medium, the medium was centrifuged on $2,500 \mathrm{rpm}$ for $10 \mathrm{~min}$ at $4^{\circ} \mathrm{C}$. Cell-free supernatants were tested for their antibacterial activity by using the disk-diffusion method [10]. The inhibition zones were observed after 24 hours of incubation.

\section{Results and Discussion}

Isolation of catfish-autochthonous bacteria was carried out to obtain potential candidates for fish probiotic. Digestive tract organs of catfish (stomach and intestines) were used as samples. According to Sugita et al. [11], fish intestine is the target organ for isolating aerobic and anaerobic heterophilic bacteria. The microflora from the fish digestive tract are capable of producing bioessential substances. For these reasons, the authochthonous bacteria are the important source for probiotic.

Nine isolates showed clear zones as an indication for producing acid in the medium (Figure 1). Addition of calcium carbonate $\left(\mathrm{CaCO}_{3}\right)$ can be used for selecting lactic acid bacteria $[12,13]$. The medium of MRSA is a common medium for isolating lactic acid bacteria. Among colonies, the morphological characteristics were as follows: a round colony form, flat edges, and white to creamy white color (Table 1).

Colony morphology and cell morphology of all bacterial isolates have almost the same character. All isolates were 
TABLE 1: Morphological characterization of purified isolates.

\begin{tabular}{|c|c|c|c|c|c|c|c|c|}
\hline \multirow{2}{*}{ No } & \multicolumn{7}{|c|}{ Colony observation } & \multirow{2}{*}{ Gram } \\
\hline & Code & Colony size & Form & Color & Elevation & Edge & Surface & \\
\hline 1 & $\mathrm{C} 1$ & Small & Circular & Milky white & Flat & Entire & Smooth glistening & Positive \\
\hline 2 & $\mathrm{C} 2$ & Moderate & Circular & Milky white & Flat & Entire & Smooth glistening & Positive \\
\hline 3 & $\mathrm{C} 3$ & Small & Circular & Milky white & Flat & Entire & Smooth & Positive \\
\hline 4 & $\mathrm{C} 4$ & Small & Circular & Milky white & Flat & Entire & Smooth glistening & Positive \\
\hline 5 & C5 & Small & Circular & Milky white & Flat & Entire & Smooth glistening & Positive \\
\hline 6 & C6 & Moderate & Circular & Milky white & Flat & Entire & Smooth glistening & Positive \\
\hline 7 & $\mathrm{C} 7$ & Moderate & Circular & White & Flat & Entire & Smooth & Positive \\
\hline 8 & $\mathrm{C} 8$ & Small & Circular & Milky white & Flat & Entire & Smooth glistening & Positive \\
\hline 9 & $\mathrm{C} 9$ & Large & Circular & Creamy white & Flat & Entire & Smooth glistening & Positive \\
\hline
\end{tabular}

TABLE 2: Antibacterial activity of isolated bacteria from catfish (Clarias sp.).

\begin{tabular}{|c|c|c|c|c|c|c|c|c|c|}
\hline \multirow{3}{*}{ No } & \multirow{3}{*}{ Isolate code } & \multicolumn{8}{|c|}{ Diameter of inhibition zone $(\mathrm{mm})$} \\
\hline & & \multicolumn{2}{|c|}{ Vibrio harveyi } & \multicolumn{2}{|c|}{ Vibrio alginolyticus } & \multicolumn{2}{|c|}{ Edwardsiella tarda } & \multicolumn{2}{|c|}{ Aeromonas hydrophila } \\
\hline & & Original & Neutralized & Original & Neutralized & Original & Neutralized & Original & Neutralized \\
\hline 1 & UBL1 & $19.1 \pm 2.4$ & $16.2 \pm 4.9$ & $18.4 \pm 2.2$ & $16.18 \pm 1.98$ & $6.3 \pm 1.67$ & $6.1 \pm 1.1$ & $17.8 \pm 3.1$ & $16.1 \pm 2.2$ \\
\hline 2 & UBL2 & & - & & - & $6.2 \pm 0.3$ & $6.2 \pm 0.0$ & & - \\
\hline 3 & UBL3 & & - & & - & $6.4 \pm 0.1$ & $6.1 \pm 0.0$ & & - \\
\hline 4 & UBL4 & & - & & - & $6.6 \pm 1.1$ & & & - \\
\hline 5 & UBL5 & & - & & - & $6.1 \pm 0.1$ & $6.1 \pm 1.2$ & & $7.21 \pm 3.6$ \\
\hline 6 & UBL6 & & - & & - & $6.5 \pm 0.0$ & & & - \\
\hline 7 & UBL7 & & - & & - & $6.5 \pm 0.1$ & $6.1 \pm 0.2$ & & - \\
\hline 8 & UBL8 & & - & & - & $6.1 \pm 0.0$ & $6.2 \pm 0.2$ & & $6.1 \pm 2.3$ \\
\hline 9 & UBL9 & & - & & - & $6.8 \pm 04$ & $6.5 \pm 0.2$ & & - \\
\hline
\end{tabular}

Original: crude extract without $\mathrm{pH}$ adjustment. Neutralized: sample with neutralization (pH 7.0 \pm 0.2$)$.

round shaped colonies. Most colonies were milky white and one was creamy white. Colony sizes ranged from $0.25 \mathrm{~mm}$ to $2.0 \mathrm{~mm}$. The bacterial cells were rod-shaped and Grampositive.

The pure isolates obtained were then tested for their antibacterial ability using Vibrio harveyi, V. alginolyticus, Edwardsiella tarda, Pseudomonas aeruginosa, and Aeromonas hydrophila. The antagonistic assay showed that only one bacterial isolate had broad-spectrum antibacterial activity (code UBL1) compared with other isolates (Table 2). Two bacterial isolates, namely UBL5 and UBL8 had an antibacterial activity against two indicator bacteria (E. tarda and $A$. hydropjyla).

Molecular identification was performed on three isolates which showed an antibacterial activity. The results of $16 \mathrm{~s}$ rDNA analysis indicated that the isolates with codes of UBL1, UBL5, and UBL8 were Bacillus velezensis, Bacillus amyloliquifaciens, and Bacillus cereus, respectively. The sequence of the isolated bacteria, Bacillus velezensis, Bacillus amyloliquifaciens, and Bacillus cereus, was deposited into Genebank under the accession number of MN640841, MN640842, and MN640843, respectively.

The isolates were then compared with reference sequences species from NCBI. Phylogenetic analysis showed that all bacteria have high similarity with those from Bacillus species. Compared to the lactic acid-producing bacteria, such as Lactobacillus Casei and L. paracasei, those bacteria were quite different. B. amyloliquifaciens had a close relation with $B$. velezensis. Initially, B. velezensis was classified as
B. amyloliquefaciens, yet during 2016-2017, they were reclassified [14].

This study was failed to specifically obtain lactic acid bacteria (Lactobacillus sp.). Inspite of the isolation using the MRSA medium, all three bacteria were identified as nonlactic acid bacteria. Targeted bacteria in this research are lactic acid bacteria. Hence, the MRSA medium was applied in all isolation procedures. The result indicated that nonlactic acid bacteria, Bacillus sp. were able to grow in the MRSA medium.

The clear zone around colonies indicated that the bacteria were able to produce acid substances. Bacillus sp. as non-lactic acid bacteria was competent in producing acids. Several Bacillus were able to produce notable amount of l-lactic acid bacteria either under aerobic or anaerobic condition [15-17]. This is the main reason for Bacillus sp. growth with a clear zone in MRS agar medium. The ability of Bacillus sp. to grow on MRS agar medium has been also confirmed by Poormontaseri et al. [18]. For this reason, it is noted that, on the basis of the medium composition, the MRS agar is not quite specific for the isolation of lactic acid bacteria from the gastrointestinal tract of catfish.

Gene cluster analysis on the Bacillus species revealed that PKS and NRPS gene cluster have existed only in B. cereus. Three gene clusters, Polyketide synthase (PKS), Nonribosomal peptide synthetase (NRPS) type I, and hybrid pathway, were found in $B$. cereus [19-21]. Furthermore, $B$. velezensis and $B$. amyloliquefaciens have an NRPS gene cluster. Thirteen secondary metabolite clusters were 
identified on B. velezensis CC09 and B. amyloliquefaciens [22]. Several productions of antimicrobial-volatile compounds, acetoin, and 2-butanone can also be produced by $B$. velezensis or B. subtilis [23].

Bacillus sp. is capable of spore-forming. Compared with the lactic acid bacteria, spore-forming bacteria have several advantages, such as a higher survival rate on the gastrointestinal tract and stability during processing and storage [24]. Therefore, acid-producing bacteria (B. velezensis, B. cereus, and B. amyloliquefaciens) are the best candidate for probiotic.

\section{Conclusion}

Nine bacterial isolates from catfish gastrointestinal tracts were isolated. Two isolates exhibited antibacterial activity on more than one tested bacteria. One isolate showed a broad spectrum antibacterial activity. We here reported that the Bacillus velezensis UBL1, Bacillus amyloliquifaciens UBL5, and Bacillus cereus UBL8 produce acids and they have an antibacterial activity. Acid and secondary metabolites are a plausible cause of antibacterial effect on those three bacteria.

\section{Data Availability}

The data used to support the findings of this study are included within the article.

\section{Conflicts of Interest}

The authors declare no conflicts of interest.

\section{Acknowledgments}

The authors thank the Ministry of Research, Technology, and Higher Education, Republic of Indonesia, for providing funding and Dr. Sri Dayuti for preparing the materials for the research. The grant for this research was provided by Directorate Research and Community Services, under the contract number 054/SP2H/LT/DRPM/2019.

\section{References}

[1] M. Rahman, Herliwati, and A. A. Prihanto, "Phosphor-based carrying capacity of riam kanan river, South kalimantan on caged fish farming," AACL Bioflux, vol. 10, pp. 1091-1097, 2017.

[2] D. Asem, V. V. Leo, A. K. Passari et al., "Evaluation of gastrointestinal bacterial population for the production of holocellulose enzymes for biomass deconstruction," PLoS One, vol. 12, no. 10, Article ID e0186355, 2017.

[3] S. A. Bora, M. J. Kennett, P. B. Smith, A. D. Patterson, and M. T. Cantorna, "The gut microbiota regulates endocrine vitamin D metabolism through fibroblast growth factor," Frontier Immunology, vol. 23, no. 9, p. 408, 2018.

[4] S. Brugman, W. Ikeda-Ohtsubo, S. Braber, G. Folkerts, C. M. J. Pieterse, and P. A. H. M. Bakker, "A comparative review on microbiota manipulation: lessons from fish, plants, livestock, and human research," Frontiers Nutrition, vol. 5, no. 80, 2018.
[5] I. de Bruijn, Y. Liu, G. F. Wiegertjes, and J. M. Raaijmakers, "Exploring fish microbial communities to mitigate emerging diseases in aquaculture," FEMS Microbiology Ecology, vol. 94, no. 1, pp. 1-12, 2018.

[6] A. M. Tarnecki, M. Wafapoor, R. N. Phillips, and N. R. Rhody, "Benefits of a Bacillus probiotic to larval fish survival and transport stress resistance," Scientific Reports, vol. 9, p. 4892, 2019.

[7] M. J. Zorriehzahra, S. T. Delshad, M. Adel et al., "Probiotics as beneficial microbes in aquaculture: an update on their multiple modes of action: a review," Veterinary Quarterly, vol. 36, no. 4, pp. 228-241, 2016.

[8] R. Meidong, S. Doolgindachbaporn, K. Sakai, and S. Tongpim, "Isolation and selection of lactic acid bacteria from Thai indigenous fermented foods for use as probiotics in tilapia fish Oreochromis niloticus," AACL Bioflux, vol. 10, no. 2, pp. 445-463, 2017.

[9] A. Dereeper, V. Guignon, G. Blanc et al., "Phylogeny.fr: robust phylogenetic analysis for the non-specialist," Nucleic Acids Research, vol. 36, pp. 465-469, 2008.

[10] A. Chamidah and A. A. Prihanto, "Hardoko, "Antibacterial activities of $\beta$-glucan (laminaran) against gram-negative and gram-positive bacteria," AIP Conference Proceedings, vol. 1844, Article ID 020011, 2017.

[11] H. Sugita, J. Takahashi, and Y. Deguchi, "Production and consumption of biotin by the intestinal microflora of cultured freshwater fishes," Bioscience, Biotechnology, and Biochemistry, vol. 56, no. 10, pp. 1678-1679, 1992.

[12] Y.-S. Chen, H.-C. Wu, and F. Yanagida, "Isolation and characteristics of lactic acid bacteria isolated from ripe mulberries in Taiwan," Brazilian Journal of Microbiology, vol. 41, no. 4, pp. 916-921, 2010.

[13] N. Hwanhlem, S. Buradaleng, S. Wattanachant, S. Benjakul, A. Tani, and S. Maneerat, "Isolation and screening of lactic acid bacteria from Thai Traditional fermented fish (plasom) and production of plasom from selected strains," Food Control, vol. 22, no. 3-4, pp. 401-407, 2011.

[14] C. A. Dunlap, S.-J. Kim, S.-W. Kwon, and A. P. Rooney, "Bacillus velezensis is not a later heterotypic synonym of Bacillus amyloliquefaciens; Bacillus methylotrophicus, Bacillus amyloliquefaciens subsp. plantarum and 'Bacillus oryzicola' are later heterotypic synonyms of Bacillus velezensis based on phylogenomics," International Journal of Systematic and Evolutionary Microbiology, vol. 66, no. 3, pp. 1212-1217, 2016.

[15] O. Hitomi and Y. Masahito, "L-lactic acid production by Bacillus sp. in anaerobic and aerobic culture," Journal of Fermentation and Bioengineering, vol. 81, pp. 272-274, 1996.

[16] M. A. Abdel-Rahman, Y. Tashiro, and K. Sonomoto, "Recent advances in lactic acid production by microbial fermentation processes," Biotechnology Advances, vol. 31, no. 6, pp. 877902, 2013.

[17] P. Poudel, Y. Tashiro, and K. Sakai, "New application of Bacillus strains for optically purel-lactic acid production: general overview and future prospects," Bioscience, Biotechnology, and Biochemistry, vol. 80, no. 4, pp. 642-654, 2016.

[18] P. Poormontaseri, R. Ostovan, E. Berizi, and S. Hosseinzadeh, "Growth rates of Bacillus species probiotics using various enrichment media," International Journal of Nutrition Science, vol. 2, pp. 39-42, 2017.

[19] B. M. Kevany, D. A. Rasko, and M. G. Thomas, "Characterization of the complete zwittermicin A biosynthesis gene cluster from Bacillus cereus," Applied and Environmental Microbiology, vol. 75, no. 4, pp. 1144-1155, 2009. 
[20] J. L. Milner, E. A. Stohl, and J. Handelsman, "Zwittermicin A resistance gene from Bacillus cereus," Journal of Bacteriology, vol. 178, no. 14, pp. 4266-4272, 1996.

[21] E. A. Stohl, J. L. Milner, and J. Handelsman, “Zwittermicin A biosynthetic cluster," Gene, vol. 237, no. 2, pp. 403-411, 1999.

[22] X.-C. Cai, C.-H. Liu, B.-T. Wang, and Y.-R. Xue, "Genomic and metabolic traits endow Bacillus velezensis CC09 with a potential biocontrol agent in control of wheat powdery mildew disease," Microbiological Research, vol. 196, pp. 89-94, 2017.

[23] B. Audrain, M. A. Farag, C.-M. Ryu, and J.-M. Ghigo, "Role of bacterial volatile compounds in bacterial biology," FEMS Microbiology Reviews, vol. 39, no. 2, pp. 222-233, 2015.

[24] J. Bader, A. Albin, and U. Stahl, "Spore-forming bacteria and their utilisation as probiotics," Beneficial Microbes, vol. 3, no. 1, pp. 67-75, 2012. 